\title{
An efficient method for the synthesis of substituted $\mathrm{N}$-aryl lactams
}

\author{
Devdutt Chaturvedi $^{i *}$, Amit K. Chaturvedi ${ }^{b}$, Pragyandip P. Dash ${ }^{\mathrm{a}}$ and Nisha Mishra ${ }^{\mathrm{c}}$
}

\begin{abstract}
${ }^{a}$ Laboratory of Medicinal Chemistry, Amity Institute of Pharmacy, Amity University Uttar Pradesh, Lucknow Campus, Lucknow-226028, U. P., India. ${ }^{b}$ Department of Chemical Sciences, GLA University, Mathura-281406, U. P., India.

${ }^{c}$ Synthetic Research Laboratory, Department of Chemistry, BSA PG College, Mathura-281004

C H R O N I C L E

\section{Article history:}

Received October 21, 2014

Received in revised form

January 29, 2015

Accepted 10 March 2015

\begin{tabular}{l} 
A B S T R A C T \\
\hline A quick, efficient, and one-pot method for the synthesis of substituted $N$-aryl lactams through \\
the reaction of various kinds of corresponding substituted arenes with a variety of $\omega$-azido \\
alkanoic acids using trifluoromethanesulfonic acid (triflic acid) at room temperature, by in- \\
situ involvement of Friedel-Crafts reaction followed by intramolecular Schmidt rearrangement \\
was developed, and afforded good to excellent yields.
\end{tabular}
\end{abstract}

Available online

16 March 2015

Keywords:

Arenes

$\omega$-Azido alkanoic acid

Triflic acid

Substituted $N$-aryl lactams (c) 2015 Growing Science Ltd. All rights reserved.

\section{Introduction}

The substituted $N$-aryl lactam moiety is encountered in a plethora of structurally-diverse natural products and drug candidates ${ }^{1}$ and has also attracted much attention due to its diverse arrays of potential biological activities, such as applications involving anti-cancer, ${ }^{2}$ anti-microbial, ${ }^{3}$ antidiabetic, ${ }^{4}$ anti-CNS, ${ }^{5}$ anti-convulsants ${ }^{6}$ and agrochemicals ${ }^{7}$ etc. Moreover, this structural moiety has also been explored as an useful synthon for the synthesis of structurally diverse complex heterocycles such as benzo-[a]-quinazolidine-2-ones, ${ }^{8}$ hexahydropyrido-[3,4-c]-[1,5]-benzothiazepines, ${ }^{9}$ 5(diethoxyphosphoryl)-1-aryl-2-alkyl/aryl-2,3-dihydro-4-pyridones, ${ }^{10}$ 3-aminopiperidines, ${ }^{11}$ methyl indolo-[2,3-a]quinazolidin-2-acetate, ${ }^{12}$ and synthesis of various alkaloids such as guettardine, 15 epiguettardine, ${ }^{13}$ E-azaburnamine, ${ }^{14}$ makaluvamine A \& C, ${ }^{15}$ veiutamine, ${ }^{16}$ and synthesis of the fundamental tetracyclic skeleton of ervitsine and 20-de-ethylidine-6,16-dihydro analogues. ${ }^{17}$ In view of their importance and wide applications, their synthesis has gained considerable attention, and therefore, become a focus of synthetic organic chemistry.

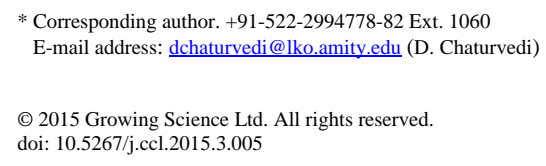


Traditional synthesis of substituted $N$-aryl lactams involved through the direct coupling reaction of substituted aryl halides with cyclic amides catalyzed by a transition metal catalyst. ${ }^{18}$ So far significant improvements have been achieved in Pd-catalyzed amide arylation reactions ${ }^{19}$ but the method remains hard to apply these reactions to a large and industrial scale syntheses due to high cost of Pd and the difficulty in removing Pd residues from the polar reaction products. An alternative method for aryl amidation involves $\mathrm{Cu}$-catalyzed Goldberg reaction between cyclic amides and aryl iodides. ${ }^{20}$ This method is attractive from economic standpoint because $\mathrm{Cu}$ is much cheaper than Pd. Despite this advantage, the Goldberg reaction is not a popular reaction in organic chemistry due to the necessity to use temperatures as high as $210^{\circ} \mathrm{C}$, highly polar aprotic solvents, strong bases such as alkoxides and $\mathrm{NaH}$, large amounts of the nucleophile and often large amounts of Cu catalysts. In recent years, several kinds of efficient ligands have been used to promote this reaction such as diamines. ${ }^{21}$ diimines, ${ }^{22}$ aminoacids, ${ }^{23} \beta$-ketoesters, ${ }^{24}$ and diols. ${ }^{25}$ Some of the other multi-step synthetic routes for the synthesis of substituted $N$-aryl lactams have also been reported. ${ }^{26}$ The majority of the above mentioned routes are associated with several drawbacks such as low reactivity, requirement of large amount of catalysts and ligands, costly, toxic and moisture sensitive nature of catalysts, harsh reaction conditions, tedious work-up, longer reaction times, generation of toxic byproducts and, sometimes, two or more steps. Therefore, there is continued interest in developing new, efficient, and safer protocols employing mild reaction conditions. Recently, we have reported an efficient method for the synthesis of substituted Naryl lactams from the corresponding arenas and $\omega$-azido alkanoic acid chloride employing catalytic amount of $\mathrm{EtAlCl}_{2}$ and $\mathrm{BF}_{3} \mathrm{OEt} 2$ respectively. ${ }^{27}$ We report herein an efficient and mild protocol for the synthesis of substituted $N$-aryl lactams starting from their corresponding substituted arenes using a variety of $\omega$-azido alkanoic acids mediated by triflic acid (trifluoromethanesulfonic acid) at room temperature. To the best of our knowledge, this is the first report for the efficient and mild one-pot synthesis of substituted $\mathrm{N}$-aryl lactams from the corresponding substituted arenes using triflic acid, which is exploring new interesting chemistry (through cascade reactions of Friedel-Crafts reaction followed by Schmidt rearrangement) than the reported methods and thus exploring a novel synthetic route.

\section{Results and Discussion}

The $\omega$-azido alkanoic acids 4, 5, 6 are key intermediates for this single-step coupling methodology and have been synthesized from their corresponding cyclic ketones 1, 2, 3 respectively, following the standard reported procedure (Scheme 1). ${ }^{28}$ Initially, a reaction of 1,2-dimethoxybenzene (7) with a 4 azidobutanoic acid (5) ( $\mathrm{n}=1$ ) using triflic acid in dry $\mathrm{CH}_{2} \mathrm{Cl}_{2}$ was tried at room temperature (entry 1) and the corresponding 1,2-dimethoxy $N$-aryl lactam product formation was indeed realized.

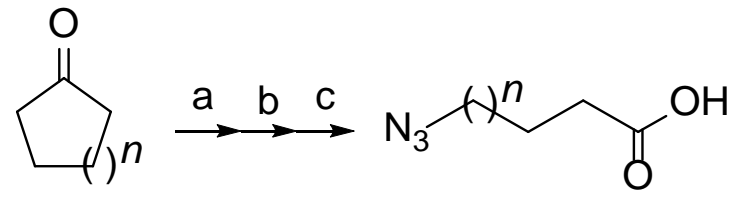
1, $\mathrm{n}=1$, Cyclopentanone
$4, \mathrm{n}=1$
2, $\mathrm{n}=2$, Cyclohexanone
$5, \mathrm{n}=2$
3, $\mathrm{n}=3$, Cycloheptanone
$6, n=3$

Scheme 1. Method (a) $\mathrm{HCO}_{2} \mathrm{H} / \mathrm{H}_{2} \mathrm{O}_{2}, \mathrm{H}_{2} \mathrm{O}, 97 \%$; (b) $\mathrm{HBr}$ (aq., 48\%)/ $\mathrm{H}_{2} \mathrm{SO}_{4}, 94 \%$; (c) $\mathrm{NaN}_{3}, \mathrm{DMF}$, $98 \%$ 

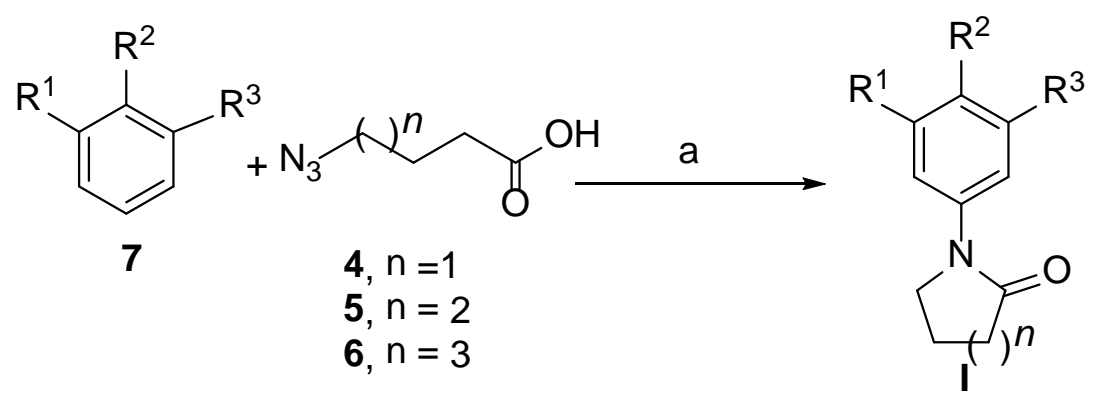

Scheme 2. Method (a): Triflic acid, dry $\mathrm{CH}_{2} \mathrm{Cl}_{2}$, 20-60 min., 62-98\%

Table 1. Conversion of various substituted arenes into substituted $N$-aryl lactams of general formula $\mathbf{I}^{\text {a }}{ }^{2}$

\begin{tabular}{|c|c|c|c|c|c|c|}
\hline Entry & $\mathbf{R}^{1}$ & $\mathbf{R}^{2}$ & $\mathbf{R}^{3}$ & $\mathrm{n}$ & Time, min. & Yield, \% \\
\hline 1 & $\mathrm{OMe}$ & $\mathrm{OMe}$ & $\mathrm{H}$ & 1 & 25 & 92 \\
\hline 2 & $\mathrm{OMe}$ & $\mathrm{H}$ & OMe & 1 & 25 & 90 \\
\hline 3 & $\mathrm{OMe}$ & $\mathrm{OMe}$ & $\mathrm{OMe}$ & 1 & 20 & 98 \\
\hline 4 & $\mathrm{OMe}$ & $\mathrm{H}$ & OMe & 2 & 25 & 88 \\
\hline 5 & $\mathrm{OMe}$ & $\mathrm{OMe}$ & $\mathrm{OMe}$ & 2 & 20 & 96 \\
\hline 6 & $\mathrm{OMe}$ & $\mathrm{OMe}$ & $\mathrm{H}$ & 2 & 25 & 85 \\
\hline 7 & OMe & $\mathrm{OMe}$ & $\mathrm{H}$ & 3 & 30 & 80 \\
\hline 8 & OMe & $\mathrm{H}$ & OMe & 3 & 30 & 82 \\
\hline 9 & OMe & $\mathrm{OMe}$ & $\mathrm{OMe}$ & 3 & 25 & 89 \\
\hline 10 & $\mathrm{Me}$ & Me & $\mathrm{H}$ & 1 & 30 & 90 \\
\hline 11 & $\mathrm{Me}$ & $\mathrm{H}$ & $\mathrm{Me}$ & 1 & 30 & 88 \\
\hline 12 & Me & Me & Me & 1 & 25 & 93 \\
\hline 13 & $\mathrm{Me}$ & Me & $\mathrm{H}$ & 2 & 30 & 87 \\
\hline 14 & Me & $\mathrm{H}$ & Me & 2 & 30 & 85 \\
\hline 15 & Me & Me & Me & 2 & 25 & 94 \\
\hline 16 & Me & Me & $\mathrm{H}$ & 3 & 35 & 79 \\
\hline 17 & Me & $\mathrm{H}$ & Me & 3 & 35 & 83 \\
\hline 18 & Me & $\mathrm{Me}$ & Me & 3 & 30 & 85 \\
\hline 19 & $\mathrm{CO}_{2} \mathrm{Me}$ & $\mathrm{H}$ & $\mathrm{CO}_{2} \mathrm{Me}$ & 1 & 40 & 72 \\
\hline 20 & $\mathrm{CO}_{2} \mathrm{Me}$ & $\mathrm{CO}_{2} \mathrm{Me}$ & $\mathrm{H}$ & 1 & 40 & 75 \\
\hline 21 & $\mathrm{CO}_{2} \mathrm{Me}$ & $\mathrm{CO}_{2} \mathrm{Me}$ & $\mathrm{CO}_{2} \mathrm{Me}$ & 1 & 50 & 70 \\
\hline 22 & $\mathrm{CO}_{2} \mathrm{Me}$ & $\mathrm{H}$ & $\mathrm{CO}_{2} \mathrm{Me}$ & 2 & 40 & 69 \\
\hline 23 & $\mathrm{CO}_{2} \mathrm{Me}$ & $\mathrm{CO}_{2} \mathrm{Me}$ & $\mathrm{H}$ & 2 & 40 & 71 \\
\hline 24 & $\mathrm{CO}_{2} \mathrm{Me}$ & $\mathrm{CO}_{2} \mathrm{Me}$ & $\mathrm{CO}_{2} \mathrm{Me}$ & 2 & 50 & 65 \\
\hline 25 & $\mathrm{CO}_{2} \mathrm{Me}$ & $\mathrm{H}$ & $\mathrm{CO}_{2} \mathrm{Me}$ & 3 & 50 & 67 \\
\hline 26 & $\mathrm{CO}_{2} \mathrm{Me}$ & $\mathrm{CO}_{2} \mathrm{Me}$ & $\mathrm{H}$ & 3 & 50 & 65 \\
\hline 27 & $\mathrm{CO}_{2} \mathrm{Me}$ & $\mathrm{CO}_{2} \mathrm{Me}$ & $\mathrm{CO}_{2} \mathrm{Me}$ & 3 & 60 & 62 \\
\hline
\end{tabular}

aproducts were characterized by IR, NMR and MS data, which were identical to previously reported values. ${ }^{27}$

Product formation was further confirmed through the appearance of an amidic peak at $\sim 1660 \mathrm{~cm}^{-1}$ in IR. The identification of the desired product was further confirmed through various spectroscopic and analytical techniques and was further confirmed through our reported authentic samples. ${ }^{27}$ This reaction was also tried in various dry organic solvents such as chloroform, acetonitrile, methanol, acetone, DMSO, DMF, $\mathrm{CH}_{2} \mathrm{Cl}_{2}$ etc. and thus found that dry $\mathrm{CH}_{2} \mathrm{Cl}_{2}$ is best among all in carrying out this transformation at room temperature. Then, we optimized the scope of this method through the 
reaction of a variety of 3,4,5-substituted arenes 7 containing electron releasing/electron withdrawing groups with different kinds of $\omega$-azido alkanoic acids 4, 5, 6 (Scheme 2). Thus, a variety of $N$-aryl lactams were synthesised and characterized through the IR, NMR, and mass spectral data. It was further realized that the yields of the $N$-aryl lactam was depend upon the type of substitution on the aromatic ring of the corresponding arene used. Furthermore, by introducing an electron releasing group at aromatic nucleus of the arene led to increasing yield of the substituted $N$-aryl lactam and by introducing electron withdrawing groups led to decrease in yield as depicted in Table 1.

We proposed that triflate of $\omega$-azido alkanoic acids will form intermediate II through the FriedelCrafts acylation reaction, which on subsequent 1,2-shift (i.e. C-N) of aryl migration of intermediate III through the intramolecular Schmidt rearrangement led to the formation of the desired substituted $\mathrm{N}$-aryl lactam I (Scheme 3, Pathway I). Furthermore, the acylated compound II may also form nitrene intermediate IV which on subsequent $\mathbf{C}$-H insertion may form intermediate $\mathbf{V}$, electronic rearrangement of $\mathbf{V}$ may led to the formation of the corresponding $N$-aryl lactam of general formula $\mathbf{I}$ (Scheme 3, Pathway II).<smiles>[R]c1cc(C(=O)CCC([Y])[N+]#N)cc([R])c1[R]</smiles>

II

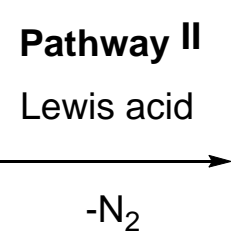

(c)

Triflic acid<smiles>[R]c1cc(C(=O)Cc2ccc[nH]2)c([R])c([R])c1[R]</smiles>

IV

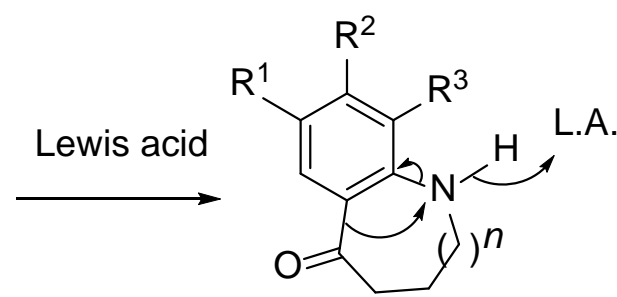

V

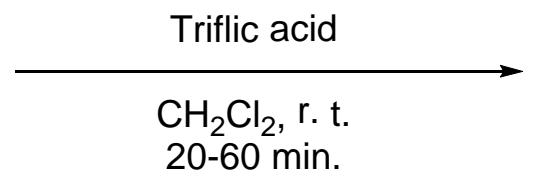

$(62-98 \%)$

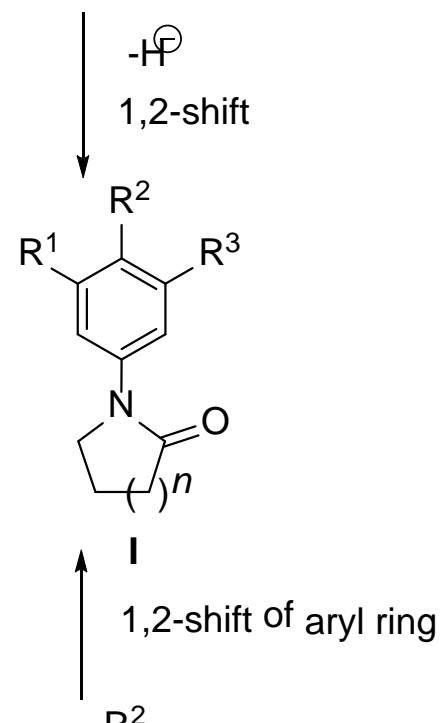<smiles>[R]c1cc(C2([O-])CCCC2)cc([R])c1[R]</smiles>

III

Scheme 3. Proposed mechanism of formation of substituted $N$-aryl lactams of general formula $\mathbf{I}$ 
To further validate this methodology, a reaction of 1,2-dimethoxybenzene was tried with previously synthesized 4-bromobutanoic acid chloride employing triflic acid afforded the corresponding acylated bromo-product through the Friedel-Crafts reaction, which on treatment with $\mathrm{NaN}_{3}$ afforded the corresponding 4-azidoacylated compound III. Treatment of compound III with triflic acid afforded the corresponding $\mathrm{N}$-aryl lactam through the Schmidt rearrangement (Scheme 4). The spectral data of the synthesized compound was correlated with the $N$-aryl lactam compound (Tab. 1 , entry 1 ) synthesized through the direct coupling method.<smiles>COc1ccc(N2CCCC2=O)cc1OC</smiles>

Scheme 4. Method (a): 4-Bromobutanoyl chloride, triflic acid; (b) NaN3, DMF; (c): Triflic acid, dry $\mathrm{CH}_{2} \mathrm{Cl}_{2}$

\section{Conclusions}

In conclusion, we have developed an efficient and novel method for the synthesis of substituted $N$ aryl lactams through the reaction of corresponding arenes with $\omega$-azido alkanoic acids employing triflic acid at room temperature. This is a new and one-pot method using catalytic amount of triflic acid which afforded high yields (62-98\%) of the desired substituted $N$-aryl lactams in shortest reaction time (20$60 \mathrm{~min}$.) and dominates over the reported procedures in respect of milder reaction conditions, high yields, and shorter reaction time.

\section{Experimental}

Chemicals were procured from Merck, Aldrich, and Fluka. Reactions were carried out under argon. IR spectra 4000-200 $\mathrm{cm}^{-1}$ were recorded on Bomem MB-104-FTIR spectrophotometer using neat technique, whereas NMRs were scanned on an AC-300F, NMR (300 MHz \& 75MHz) instrument using $\mathrm{CDCl}_{3}$ and TMS as internal standard. Elemental analysis were conducted by means of a Carlo-Erba EA 1110-CNNO-S analyzer and agreed favorably with calculated values.

4.1 Typical experimental procedure for the synthesis of substituted N-aryl lactams:

An equimolar amount of substituted arene and the corresponding $\omega$-azido alkanoic acid were taken in dry $\mathrm{CH}_{2} \mathrm{Cl}_{2}\left(25 \mathrm{ml}\right.$ ), and stirred for $10 \mathrm{~min}$. at room temperature. To this, $1 / 10^{\text {th }}$ molar amount (with respect to arene) of Lewis acid was added slowly in 2-3 small portions at room temperature. The reaction was continued until completion ( $c f$ Table 1 ) as confirmed by TLC. The reaction mixture was then poured into distilled water $(50 \mathrm{ml})$ and extracted with dichloromethane. The organic layer was separated and dried over anhydrous sodium sulfate and then concentrated to afford the desired substituted $N$-aryl lactam compound.

\subsection{Data of selected compounds}

1-(3,4-Dimethoxyphenyl)piperidin-2-one (Table 1, entry 1)

Colorless oil; ${ }^{1} \mathrm{H}$ NMR (300MHz, $\left.\mathrm{CDCl}_{3}\right) \delta=1.92-1.95(\mathrm{~m}, 4 \mathrm{H}), 2.55$ (t, $\left.J=6.2 \mathrm{~Hz}, 2 \mathrm{H}\right), 3.61(\mathrm{t}, J=$ $5.5 \mathrm{~Hz}, 2 \mathrm{H}), 3.86$ (s, 3H), 3.87 (s, 3H), 6.77-6.78 (m, 2H), 6.86-6.88 (m, 1H); ${ }^{13} \mathrm{C}$ NMR (75 MHz, 
$\left.\mathrm{CDCl}_{3}\right) \delta=21.3,23.4,32.7,52.0,55.7,55.8,110.0,111.2,118.0,136.4,147.6,149.0,170.0$; MS (EI) $\mathrm{m} / \mathrm{z} 235$ (M+, 100), 220, 166; HRMS (EI) $\mathrm{m} / \mathrm{z}$ calcd for $\mathrm{C}_{13} \mathrm{H}_{17} \mathrm{O}_{3} \mathrm{~N}(\mathrm{M}+)$ 235.1208, found 235.1208. 1-(3,5-Dimethoxyphenyl)pyrrolidin-2-one (Table 1, entry 2)

White solid, m.p. $85-86^{\circ} \mathrm{C}$; IR $\left(\mathrm{CH}_{2} \mathrm{Cl}_{2}\right): v=1069,1154,1208,1249,1275,1324,1347,1393,1478$, 1598, 1697, 2841, $2958 \mathrm{~cm}^{-1}$; ${ }^{1} \mathrm{H}$ NMR (300 MHz, $\left.\mathrm{CDCl}_{3}, \mathrm{TMS}\right): \delta=2.14$ (tt, $J=8.4 \mathrm{~Hz}, J=6.6 \mathrm{~Hz}$, $\left.2 \mathrm{H}, \mathrm{CH}_{2}\right), 2.61\left(\mathrm{t}, J=8.4 \mathrm{~Hz}, 2 \mathrm{H}, \mathrm{CH}_{2}\right), 3.80\left(\mathrm{~s}, 6 \mathrm{H}, \mathrm{OCH}_{3}\right), 3.83\left(\mathrm{t}, J=6.6 \mathrm{~Hz}, 2 \mathrm{H}, \mathrm{CH}_{2}\right), 6.27(\mathrm{t}, J=$ $2.4 \mathrm{~Hz}, 1 \mathrm{H}, \mathrm{Ar}$ ), 6.86 (d, $J=2.4 \mathrm{~Hz}, 2 \mathrm{H}, \mathrm{Ar}) ;{ }^{13} \mathrm{C} \mathrm{NMR}\left(75 \mathrm{MHz}, \mathrm{CDCl}_{3}\right.$, TMS): $\delta=17.8,32.9,48.9$, 55.3, 96.4, 98.3, 141.1, 160.7, 174.3; MS (EI) m/z: 221 (M+, 100), 192 (23), 178 (9), 166 (75), 162(7), 151 (5), 136 (12), 122(6), 108(5); Anal. Calcd. for $\mathrm{C}_{12} \mathrm{H}_{15} \mathrm{NO}_{3}$ : C, 65.14, H, 6.83, N, 6.33\%; Found: C, 64.99, H, 6.85, N, 6.25\%.

\section{Acknowledgements}

The corresponding author wish to thank Pro-Vice Chancellor, and Dean, Research (Science and Technology), Amity University Uttar Pradesh, Lucknow Campus, Lucknow, for his constant encouragement and support for research. Authors confirm that there is no conflict of interest inside the manuscript.

\section{References}

1. (a) Muktar T.A., Wright G. D. (2005) Streptogramins, oxazolidinones, and other inhibitors of bacterial protein synthesis. Chem. Rev.105, 529-542; (b) Horton D. A., Bourne G. T., Smythe M. L. (2003) The combinatorial synthesis of bicyclic privileged structures or privileged substructures. Chem. Rev. 103, 893-930; (c) Fischer C., Koening B. (2011) Palladium and copper mediated $N$-aryl bond formation reactions for the synthesis of biologically active compounds. Beilstein J. Org. Chem. 7, 59-74; (d) Bari S. S., Bhalla A. (2010) Spirocyclic $\beta$-lactams: Synthesis and biological evaluation of novel heterocycles. Top. Heterocycl. Chem. 22, 49-99.

2. (a) Dimmock J. R., Jha A., Zello G. A., Quail J. W., Oloo E. O., Nienaber K. H., Kowalczyk E. S., Allen T. M., Santos C. L., De Clercq E., Balzarini J., Manavathu E. K., Stables J. P. (2012) Cytotoxic $\mathrm{N}$-[4-(3-aryl-3-oxo-1-propenyl)phenylcarbonyl]-3,5-bis(phenylmethylene)-4-piperidones and related compounds. Eur. J. Med. Chem. 37, 961-972; (b) Jha A., Mukherjee C., Prasad A. K., Parmar V. S., De Clercq E., Balzarini J., Stables J. P., Manavathu E. K., Srivastava A., Sharma R. K., Nienaber K. H., Zello G. A., Dimmock J. R. (2007) E,E,E-1-(4-Arylamino-4-oxo-2-butenoyl)-3,5bis(arylidene)-4-piperidones: A topographical study of some novel potent cytotoxins. Bioorg. Med. Chem. 15, 5854-5865.

3. (a) Schwartz R. E., Helms G. L., Bolessa E. A., Wilson K. E., Giacobbe R. A., Tkacz J. S., Bills G. F., Liesch J. M., Zink D. L., Curotto J. E., Pramanik B., Onishi J. C. (1994) Tetrahedron 50, 16751686; (b) Das U., Das S., Bandy B., Stables J. P., Dimmock J. R. (2008) Pramanicin, a novel antimicrobial agent from a fungal fermentation. Bioorg. Med. Chem. 16, 3602-3607; (c) Das M., Molnar J., Barath Z., Bata Z., Dimmock, J. R. (2008) 1-[4-(2-Aminoethoxy)phenylcarbonyl]-3,5bis-(benzylidene)-4-oxopiperidines: A novel series of highly potent revertants of P-glycoprotein associated multidrug resistance. Bioorg. Med. Chem. Lett. 18, 3484-3487.

4. Coutrot P., Claudel S., Didierjean C., Grison C. (2006) Stereoselective synthesis and glycosidase inhibitory activity of 3,4-dihydroxy-pyrrolidin-2-one-3,4-dihydroxy-piperidin-2-one and 1,2dihydroxy-pyrrolizidin-3-one. Bioorg. Med. Chem. Lett. 16, 417-420.

5. Baures P. W., Eggleston D. S., Erhard K. F., Cieslinski L. B., Torphy T. J., Christensen S. B. (1993) Crystal structure, absolute configuration, and phosphodiesterase inhibitory activity of (+)-1-(4bromobenzyl)-4-[(3-cyclopentyloxy)-4-methoxyphenyl]-2-pyrrolidinone. J. Med. Chem. 36, 32743277.

6. (a) Ho B., Crider A. M., Stables J. P. (2001) Synthesis and structure-activity relationships of potential anticonvulsants based on 2-piperidine carboxylic acid and related pharmacophores. Eur. J. Med. Chem. 36, 265-286; (b) Le Tiran A., Stables J. P., Kohn H. (2001) Functionalized amino acid 
anticonvulsants: synthesis and pharmacological evaluation of conformationally restricted analogues. Bioorg. Med. Chem. 9, 2693-2708.

7. Mitchell G., Barnes N. J., Cox J. M., Matthews I. R., Parry D. R., Pearson D. P. J., Smith S. C. (2001) ACS Symposium Series, Vol. 800, Chapter 3, pp 18-29.

8. Rubiralta M., Diez A., Balet A., Bosch J. (1987) New synthesis of benzo[a]quinolizidin-2-ones via protected 2-Aryl-4-piperidones. Tetrahedron 43, 3021-3030.

9. Kumar R. R., Perumal S. (2007) A facile synthesis and highly atom economic 1,3-dipolar cycloaddition of hexahydropyrido[3,4-c][1,5]benzothiazepines with nitrile oxide: Stereoselective formation of hexahydro[1,2,4] oxadiazolo[5,4-d]pyrido[3,4-c][1,5]-benzothiazepines. Tetrahedron 63, 7850-7857.

10. Commins D. L., Ollinger C. G. (2001) Tetrahedron Lett. 42, 4115-4118.

11. Diez A., Voldoire A., Lopez I., Rubiralta M., Segarra V., Pages L., Palacois J. M. (1995) Synthetic applications of 2-aryl-4-piperidones X: Synthesis of 3-aminopiperidines, potential substance $\mathrm{P}$ antagonists. Tetrahedron 51, 5143-5156.

12. Rubiralta M., Diez A., Vila C., Bettiol J. L., Troin Y., Sinibaldi M. E. (1992) Synthetic applications of 2-aryl-4-piperidones. VIII: Synthesis of methyl indolo-[2,3-a]quinolizidin-2-acetate. Tetrahedron Lett. 33, 1233-1236.

13. Diez A., Tona M., Rubiralta M. (1990) Synthetic applications of protected 2-aryl-4-piperidones. V. Synthesis of guettardine and 15-epiguettardine. Tetrahedron 46, 4393-4406.

14. Lopez I., Diez A., Rubiralta M. (1996) Synthetic applications of 2-aryl-4-piperidones XI: A new synthesis of the E-azaburnamine skeleton. Tetrahedron 52, 8581-8600.

15. Radisky D. C., Radisky E. S., Barrows L. R., Copp B. R., Kramer R. A., Ireland C. M. (1993) Novel cytotoxic topoisomerase II inhibiting pyrroloiminoquinones from Fijian sponges of the genus Zyzzya. J. Am. Chem. Soc. 115, 1632-1638.

16. Moro-oka Y., Fukuda T., Iwao M. (1999) The first total synthesis of veiutamine, a new type of pyrroloiminoquinone marine alkaloid. Tetrahedron Lett. 40, 1713-1716.

17. Rubiralta M., Marco M. P., Bolos J., Trape J. (1991) Synthetic applications of 2-aryl-4-piperidones. V1: Synthesis of the fundamental tetracyclic skeleton of ervitsine and its 20-deethylidene-6,16dihydro analogue. Tetrahedron 47, 5585-5602.

18. Hartwig J. F. (1998) Transition metal catalyzed synthesis of arylamines and aryl ethers from aryl halides and triflates: Scope and mechanism. Angew. Chem. Int. Ed. 37, 2046-2067.

19. Klapars A., Antilla J. C., Huang X., Buchwald S. L. (2001) A general and efficient copper catalyst for the amidation of aryl halides and the $N$-arylation of nitrogen heterocycles. J. Am. Chem. Soc. 123, 7727-7729.

20. Deng W., Wang Y. F., Zou Y., Liu L., Guo Q.-X. (2004) Amino acid-mediated Goldberg reactions between amides and aryl iodides. Tetrahedron Lett. 45, 2311-2315.

21. Klapars A., Huang X., Buchwald S. L. (2002) A general and efficient copper catalyst for the amidation of aryl halides. J. Am. Chem. Soc. 124, 7421-7428.

22. Cai Q., Zhu W., Zhang H., Zhang Y. D., Ma D. W. (2005) Preparation of $N$-aryl compounds by amino acid-promoted Ullmann-type coupling reactions. Synthesis 496-499.

23. Guo X., Rao, H.; Fu, H.; Jiang, Y.; Zhao, Y. (2006) An inexpensive and efficient copper catalyst for $N$-arylation of amines, amides and nitrogen-containing heterocycles. Adv. Synth. Catal. 348, 2197-2202.

24. Lv X., Bao W.A. (2007) $\beta$-Keto ester as a novel, efficient, and versatile ligand for copper (I)catalyzed C-N, C-O, and C-S coupling reactions. J. Org. Chem. 72, 3863-3867.

25. Kwong F. Y., Klapars A., Buchwald S. L. (2002) Copper-catalyzed coupling of alkylamines and aryl iodides: An efficient system even in an air atmosphere.Org. Lett. 4, 581-584.

26. Yang Y.-H., Shi M. (2005) Ring-expanding reaction of cyclopropyl amides with triphenylphosphine and carbon tetrahalide. J. Org. Chem. 70, 8645-8648. 
27. (a) Chaturvedi D., Chaturvedi A. K., Mishra N., Mishra V.(2012) Org. Biomol. Chem. 10, 91489151; (b) Chaturvedi D., Chaturvedi A.K., Mishra N., Mishra V. (2012) Synlett 23, 2627-2630.

28. Sankaranarayanan S., Chattopadhyay S. (1998) Asymmetric synthesis of a cytotoxic amide of Telesto riisei. Tetrahedron Assym. 9, 1345-1350. 